\title{
Biblical Spirituality and J.H. Eaton
}

Author:
Christo Lombaard ${ }^{1}$
Affiliation:
'Discipline Christian
Spirituality, University of
South Africa, South Africa
Correspondence to:
Christo Lombaard
Email:
christolombaard@gmail.com
Postal address:
PO Box 392, UNISA 0003,
South Africa
Dates:
Received: 11 Oct. 2011
Accepted: 11 May 2012
Published: 31 Aug. 2012
How to cite this article:
Lombaard, C., 2012, 'Biblical
Spirituality and J.H. Eaton',
Verbum et Ecclesia 33(1), Art.
\#685, 5 pages. http://dx.doi.
org/10.4102/ve.v33i1.685

C 2012. The Authors Licensee: AOSIS OpenJournals. This work is licensed under the Creative Commons Attribution License.
In this contribution, the nature of 'Biblical Spirituality' as an academic discipline is reviewed from a methodological perspective. Two core aspects are indicated: the importance of ancient expressions of faith (spiritualities) in the Bible, and the importance of modern expressions of faith (spiritualities) as they draw on the Bible. Based on this framework, as a first application of such a nature within the field of Biblical Spirituality, the relevant publications of an Old Testament scholar are evaluated; in this case, those of J.H. Eaton. Such an analysis opens an arena for discussion on whether this model of Biblical Spirituality holds promise for wider application.

\section{'Biblical spirituality' - discipline and methodology}

The new discipline of Biblical Spirituality finds itself at a methodological crossroad. This does not meant a 'crisis', as is often implied by the use of the phrase 'methodological crossroads', but rather, more mildly, a methodological confluence, which is inherent to this discipline. On one level, the discipline of Biblical Spirituality finds itself borne from two academic fields with vastly different methodological sensibilities. The one source discipline of Biblical Spirituality is taken for the moment as one field - Old and New Testament Studies, which has a long history of divergent, detailed methodologies. This has led to intensive scholarly debate and, thus, to further refinements and insights. The other source discipline of Biblical Spirituality, namely the academic discipline of Spirituality - as it is embedded in lived experiences of faith, that is, spirituality ${ }^{1}$ - has a different methodological heritage. In this case, the language of 'methodology' is used. Methodological descriptions within Spirituality Studies are relatively vague and therefore it would be more apt to use the word 'approaches'. There is no tradition of methodological conflict (cf. Lombaard 2011a:211-225 for a broader elucidation of this methodological background to Biblical Spirituality) - a contestation, which would always be healthy for an academic discipline.

On another level, Biblical Spirituality has been characterised over the last two decades by the search for a model, or an approach, to which to orient itself. In this search, Biblical Spirituality has been related to its two constituent disciplines, but in a sense it has also advanced on its own. In a series of publications, mostly loose standing and rarely in critical debate with one another, different scholars have drawn on a variety of personal, ecclesial, and academic impulses to formulate views on what the discipline of Biblical Spirituality could or should involve (cf. Lombaard 2008b:139-153; Mahoney 2005; Adam 2004; Schneiders 2002:133-143; the sections on Scriptural hermeneutics in Waaijman 2002; Thurston 2000:471-481; Pacini 1991:174-210; Runia 1988:175-198). Two aspects that seem to crystallise ever more clearly, is that Biblical Spirituality should have two aspects to it, which are strongly related, namely:

- ancient expressions of faith (spiritualities) in the Bible

- later, including modern expressions of faith (spiritualities) as they draw on the Bible.

Though this dual concern is not new (its roots can be traced to Second Temple Judaism), a sense has developed in different academic and church circles that a dissociation has set in between the lives of faith in or behind the biblical texts, and the lives of faith that result from these texts (or more phenomenologically formulated: the lives of faith that understand themselves as being in continuance of these ancient impulses). Thus, the discipline of Biblical Spirituality understands itself implicitly, though not monologically, as expressly seeking to bring these separate(d) parts into a greater whole.

With these two points of orientation - ancient and modern - having been identified and reflected upon, the validity of such an approach or, perhaps even, model, ought now in various ways to be tested. One way of doing so, is to seek examples of scholars who seem to have pursued such

1.When not capitalised, the term 'spirituality' here refers to the human phenomenon of seeking for meaning in this world, a search that orients itself, most commonly, to realities outside the immediate world, that is in a religious way. When capitalised, 'Spirituality' refers to the study or analysis of this phenomenon, often in an academic setting. Cf. Lombaard 2003:350. For a full discussion on the definition of spirituality, including all the relevant literature, see Lombaard 2008a:94-107. 
a dual focus in their publications. By understanding what studies have been carried out, more clarity may be gained on what ought to be performed in future.

\section{J.H. Eaton in overview}

John Eaton's publications in the field of biblical and cognate scholarship show his varied academic interests, clustered around certain focal points. These focal points may be broadly categorised into three groups: Language, Exegesis and the Continued Meaning of the Psalms (in particular). As is always the case with such classifications, these groups ought to be understood as only loosely clustering Eaton's writing: often, aspects from these groups can be seen to intermingle, and in different ways, also as historically Eaton's textual focus shifted between the Psalms and the Prophets (mostly), but seldom without the other main textual focus disappearing from his referential framework. It was to the Psalms, though, that Eaton devoted the greater part of his energies, and on which he had been the most productive. In time, furthermore, his work on the Psalms shows a growing tendency towards seeking meaning for our time from these ancient poems. The three categories identified above, to be employed below, are therefore not without grounding in what has become the life's work of John Eaton (who died in 2007). Below, each of these three focal points will be discussed in greater detail.

Eaton studied Theology and Hebrew at Cambridge, and other Semitic languages by private tuition and in Jerusalem (cf. Eaton 1978:vii-xviii). His subsequent, and life-long, professional appointment was as Reader in the Old Testament at the University of Birmingham. It is thus this academic background and professional setting that made it possible for his personal inclinations and intellectual insights to steer his academic output.

\section{Language}

Given his studies, Eaton's early publications include authoring a study manual on Hebrew (cf. Eaton 1980a:iii ${ }^{3}$ [1967]), contributing to and editing teaching texts on the Old Testament (Eaton 1976a, 1978), and editing a collection of essays on Semitics (Eaton 1979a). All these publications appeared as a series of University of Birmingham in-house published guides for students, but circulated internationally. His contributions to these volumes focussed on introductory grammar, and on small sections from the Prophets, Psalms and some Wisdom poems, usually described in their historical contexts, but with a very strong linguistic slant. The latter is so pronounced, that in the 1978 volume Eaton describes himself in an autobiographical essay as a 'Hebraist' (Eaton 1978:vii-xviii). This interest in the Hebrew language, which persisted but became less prominent in his later writings, formed an invaluable grounding for the kind of studies that would flow from Eaton's pen.

The importance of a strong grounding in the biblical languages cannot be overestimated when it comes to understanding the Bible texts in their contexts, so as with greater validity to seek continued meaning from these texts for later times (an important aspect for the discipline of Biblical Spirituality, as indicated above). In addition, this inclination of Eaton's makes possible a comparative-literary approach, which he employs at times to take into account texts from the cultures surrounding that within which the Old Testament was written (e.g. Eaton 1985:52-60; cf. Eaton 1997:1-28). Eaton's excellent grasp of Hebrew and his interest - not despite this interest but rather precisely because of it - provides a good example that the one does not preclude the other, as is at times suggested in debates on how meaningful the biblical languages could be for theological training and/or an active life of faith. More broadly put: Intellectual rigor and spiritual depth are no opposites (cf. Lombaard 2006b:912-925); much rather, they are the interdependent arms of a balancing scale.

\section{Exegesis}

The fundamental importance of the historical location of the ancient biblical texts ('First we may consider historical contexts' - Eaton 2003a:20), and thus of historical-critical exegesis, shows clearly in Eaton's work on the Psalms, with Gunkel's contributions on Formgeschichte (e.g. Gunkel 1933) the strongest influence in this respect (cf. e.g. Eaton 2003a:18-19, 55, 487-530; 1995a:47-48, 1981:1). Eaton not only employs this approach, but develops it further too, namely by identifying previously unrecognised forms in the Psalms (Eaton 1976c:67-70). The identification of Formen, as classic textual types, goes together in the Gunkelian analysis with the identification of an accompanying Sitz im Leben for each: the real life context in which such a literary form may be placed. When Eaton analyses the prophets, the political setting is of the utmost importance (e.g. Eaton 1961:19-24, 35-36, 51-55, 81-84, 121-124), but then not without an accompanying interest in the theology of these prophets in their situations (e.g. Eaton 1961:26-31). These early dual inclinations are still evident in Eaton's later major works (2003a, and from it Eaton 2004 and Eaton 2006).

In his writings on the historical backgrounds to different Old Testament texts, Eaton shows full cognisance of some of the more radical suggestions. This includes the extreme late dating possibility of some Psalms (very late 2nd century and/or very early 1st century BCE; cf. e.g. Eaton 1995a:46), but not of others, such as the possibility that the Davidic empire was a literary construction from Josianic or even postexilic times, which based itself on memories of a small tribal leadership, or on no extant history at all, to imagine a grand Israelite-Judean kingdom in earlier times. Given the link in many Psalms with King David, and given Eaton's interest in especially the royal Psalms, one would have expected these theories to find ample consideration in his works.

This is not to say that Eaton does not dare to tread radical new ground. Apart from being versed in the works of English, German and, less notably, French scholars in his fields, Scandinavian Old Testament research had the greatest impact on his most controversial exegetical stand. Eaton (1976b, 1986) attempts to extend numerically the scope of 
the royal Psalms - an interpretative position that springs from and suits well his interest in the putative cultic and/or pilgrimage feasts in ancient Israel (cf. also Eaton 1981:3-39, 89-103). Had this become an influential position (see however Wilks 2003:531-535), this contribution would have been regarded as of great importance in Old Testament science. The same interests were applied to his work on DeuteroIsaiah too (Eaton 1979b), though not to the other prophets.

For Eaton, there is a firm connection between the Psalms and torah and/or wisdom (particularly with the three famous torah Psalms 1, 19 and 119; cf. Eaton 1995a:48-52), and from there, with spirituality. The latter therefore receives broad consideration in his 1989 work, The contemplative face of Old Testament wisdom. This includes work on the biblical, international and inter-religious impulses for Spirituality, as well as some important themes in Spirituality writing (such as spiritual direction, silence, and the dark night theme - rare topics amongst Old Testament scholars). Only then does he turn to the Psalms to discuss a selection of them based on the foregoing. Such an approach characterises Eaton's 1989 work as both unique and highly valuable amongst the publications within the field we now know as Biblical Spirituality, and also as a very useful course book for retreats, for instance.

\section{Continued meaning of the Psalms}

Eaton's interest not only in understanding the ancient biblical texts, but also in 'applying' them to modern-day faith ${ }^{2}$ ('Through all kinds of psalms shines experience of God ...' Eaton 2003a:27), speaks already from some of the titles under his authorship. Titles reflecting this express commitment to lived or experienced spirituality include (with the stressed parts of the titles here italicised): 'Psalms for life: hearing and praying the book of Psalms' (2006), 'Meditating on the Psalms' (2004); 'The Psalms: a historical and spiritual commentary' (2003a); 'Mysterious messengers' (1997); 'The contemplative face of Old Testament wisdom' (1989); more broadly, reflecting core experiential themes in Spirituality writing: 'Interpreted by love' (1994), 'Festal drama in Deutero-Isaiah' (1979b; see also 1995b:347-251), and also 'Vision in worship: the relation of prophecy and liturgy in the Old Testament' (1981). The latter three titles thus mirror the strong links in Spirituality literature between interest in faith and interest in how that faith is expressed, for example in love or in liturgy.

Although prophecy and wisdom literature do feature in relation to the interest in matters spiritual with Eaton, it is the Psalms that feature most substantially. This textual focus is typical of when the Old Testament is at all brought to bear within Christian Spirituality writings (cf. Lombaard 2003:443-444), and it has its high point with Eaton in his 2003 volume, 'The Psalms: a historical and spiritual commentary'. This commentary finds its place within a firm trend over the last decade (cf. Lombaard 2006a:909-929) of writing on (aspects of) spirituality in specifically the Psalms, with the

2.This distinction, of course, remains artificial: the reading process is such an involved hermeneutical exercise that understanding and application, reading and interpretation, cannot really be divorced from one another. See specifically Le Roux (1997:410-416, 419); more generally, Thiselton (2009). other major four works being those of two Americans, Carroll Stuhlmueller's excellent 'The spirituality of the Psalms' and Walter Brueggemann's influential 'Spirituality of the Psalms' (both from 2002), the pre-eminent Spirituality scholar of our time, Dutch theologian Kees Waaijman's 'Mystiek in de Psalmen' (2004), and the Australian-British David Firth's 2005 book, which develops Brueggemann's work, titled 'Hear, o Lord. A spirituality of the Psalms'. None of these works had been published early enough for them to find reference in Eaton's commentary.

Eaton's most substantial historical-spiritual work (2003a) follows many traditional formats for the writing of commentaries, namely those of an opening section discussing the usual introductory issues, offering an own translation of each of the Psalms, and then commentary on verses grouped together. Given the spiritual slant of this publication, the brief prayer at the end of each Psalm discussion is not surprising. Continuing this inclination, with reference to the most influential critical scholars and some spiritual writings, additional brief notes are provided on each of the Psalms in an appendix, for readers interested in further background. The 2006 Psalms for life and 2004 Meditating on the Psalms American publications offer essentially the same content as his 2003a commentary, except that they contain less background detail.

The way in which the continued relevance of the ancient texts are indicated, most particularly for the Christian faith, usually includes in Eaton's work indications of what are morally difficult ideas from the Old Testament ${ }^{3}$ for latterday humanity to continue with, referring to parallel human experiences in the ancient and modern worlds, showing how certain ideas from the Old Testament are taken up and responded to within new Testament texts, and outlining the Wirkungsgeschichte or history of interpretation of the Psalms (cf. Eaton 2003a:37, 41-58). The latter is performed by considering both the more critical impulses and the more mystical impulses that comes to us from history. At times, as indicated above, Eaton draws more explicitly on Spirituality to assist in bringing the ancient texts home more fruitfully in our times.

\section{A note on style}

The importance for Eaton of literary art, that is, of good and even beautiful writing, both in what he reads and what he writes, is such that it merits a special additional note. There is namely a long-recognised link, almost instinctual, between humanity's openness to spiritual meaning and the search for beauty in life, in both the natural and cultural surroundings of humanity.

The musicality and poetry of the Psalms receive special consideration in Eaton's writings (cf. e.g. Eaton 2003a:9-19);

3.The test case here in the Psalms is always Psalm 137, with its extreme, cruel closing verses. In his works on the Psalms (cf. Lombaard 1999:139-141), Eaton's solution is always the same: neither a philosophical-anatical approach, nor a culution is always the same: neither a philosophical-analytical approach, nor a culturalcomparative analysis, or a historical-psychological explanation. His approach is always what may be termed biblical-theological: these kinds of themes may of course be found in the Old Testament, but they are certainly not dominant; compared to the positive value of the whole of the Old Testament, these mino themes ought not to be taken up for our times: rather, the focus should be on what is in fact dominant, and positive and/or beautiful, and lasting. 
for him, these aspects of the Psalms even have meditative qualities (e.g. Eaton 1989:93-9; Eaton 2006:1-3). Therefore, in his 1984 volume on the Psalms, he draws deliberately on the arts as major interpretative frames of reference with which to analyse the ancient biblical poetry. These arts include, with little surprise, poetry, music and even dance, but less traditionally also drama, and surprisingly, architecture, with a particular focus on aspects of the city of Jerusalem. For Eaton, there is something natural about finding musical 'rhythm and melody' and narrative art in the Hebrew verse (Eaton 1978:xiii-xviii), and - note the language of participation - in 'experiencing the book Job', namely as 'story ... poetry ... drama ...' (Eaton 1985:1-30 \& ix, respectively; cf. Eaton 1997:14-19). That is also why he can write, on Deutero-Isaiah: 'The style is fluent. The effect is brilliant and exciting' (Eaton 1979b:1). In doing so, Eaton is as much commenting on the ancient text as setting out the ideals for his own penmanship. One sees this fine eye for style and a feeling for the great literature of the world also in his book reviews (e.g. Eaton 2003b:627), which in addition show, even in his critical assessments, as is also the case in his more substantial writings, a sensitivity and kindness that accompanies the differences in perspective (cf. e.g. Eaton 2000:602-605).

In Eaton's academic works, the fluency of the presentation is given preference to an academic style of writing (as is the case for example with the more German orientation of thickly footnoted academic texts). This renders works clearly in the more British scholarly style: references are few, and only an informed reader can gather the allusions, rather than direct references to or quotes from, the most important academic sources. This style of writing assumes much, namely that the academically grounded reader already knows the research history of the ideas taken up in the Eaton text. This approach makes for easier reading for the reader more interested in gaining certain insights from the text. Therefore, although the content of Eaton's academic works is in fact heavily researched, the presentation is inviting. Whereas academic eyes can see the former, the eyes of those who seek nourishment of a different kind, in a less roundabout way, will find what they seek too, relatively effortlessly. For example: an Old Testament scholar may well be familiar with the debates and insights that led to the current understanding of the five-fold division of the Psalter according to the Pentateuchal corpus, or of the late redactional addition of Psalm 1 as an interpretative framing of the collection (cf. Lombaard 2000:506-514), which Eaton (2003a:42) reflects without indicating the sources of these insights. The less informed reader will however pick up these insights only, without grasping the implicit research history, in order to live by these insights. To the latter will remain hidden a most important aspect to Eaton's writings: how the 'feeling' or 'spirit' of the Psalms for him comes from Von Herder (1782/1783) and De Wette (1811); or that his positions, influenced by Mowinckel's festival placement of the Psalms (1922; this work and others reached Eaton via the mediation of Johnson 1944 \& 1967), are no longer broadly held. For such readers the how will remain a mystery, although they may well feel great sympathy for the that, namely 'the desire to go further back to the hearts of the first creators of the separate psalms' (Eaton 2003a:57-58), from which to gain 'the sense of being even now with God' (Eaton 2003b:628). Though neither of these aspects should be sacrificed for the other, and though this demands intense intellectual work from a theologian in the forms of exegesis and hermeneutics, when it comes to Bible readers' concerns, Eaton believes the text itself should be encountered first. Therefore, it should be as part of the 'experience of the Holy' (Eaton 2003a:27-40) elicited in and by the text, after which follows the more critical engagement (Eaton 1985:ix; Eaton 2003b:629). The same holds true of his more popular writing too: here, Eaton (1994 especially; cf. also 1989:92-142) employs the same kind of language sensitivities that he enjoys from the biblical texts, though in a modern context. His idiom is gripping, his examples and anecdotes attractive, his argumentation subtle and cogent, and his writing style elicits from the reader a kind of participation that is unique to the interaction between a reader and a wellwritten text.

\section{Eaton and biblical spirituality}

It is clear from the above that Eaton constitutes in his writings an example of both legs of what the discipline of Biblical Spirituality has come to entail: the Bible texts are taken seriously, in two directions. On the one hand, the ancient historical settings are of great importance. This Eaton explored in different ways, for instance by means of his interest in the languages of the ancient Near East, the placement of a text within its probable original settings (à la Gunkel), and his 'historical experimentation' in proposing theories with which he had hoped to bring about a better, more accurate understanding of his subject matter. On the other hand, Eaton had developed great sensitivity towards the interests of the modern Bible reader, which he catered to by means of a range of techniques, including drawing on spirituality, to elucidate and to 'translate' the ancient texts into our times for readers today.

In his writings, with a bi-focal interest, we see an instance of a scholar who fits the currently developing mould of Biblical Spirituality. Eaton's life's work helps in providing an instance, which illustrates at least the possibility of such an approach, affording it greater validity. Naturally, one swallow does not make a summer: methodologically, it would be prudent to develop this research track along at least the following lines:

- studying more examples of scholars who broadly fit this mould

- comparing critically the ways in which such examples fit this mould

- studying examples of scholars who do not fit this mould

- comparing critically the ways in which such examples do not fit this mould

- comparing critically the above two identified groups

- moving further afield: exploring biblical texts along the lines of the same matrix just identified (cf. e.g. Lombaard 2011b) 
- and yet more broadly: searching for different, alternate models and approaches, in order to facilitate methodological debate - which is always healthy within the emerging discipline of Biblical Spirituality.

\section{Acknowledgements}

The author declares that he has no financial or personal relationship(s) which may have inappropriately influenced him in writing this paper.

\section{References}

Adam, P., 2004, Hearing God's words: exploring biblical spirituality, Inter Varsity Press, Downers Grove.

Brueggemann, W., 2002, Spirituality of the Psalms, Fortress Press, Minneapolis.

De Wette, W.M.L., 1811, Kommentar über die Psalmen, s.n, Heidelberg.

Eaton, J.H., 2006, Psalms for life: hearing and praying the book of Psalms, Westminster John Knox Press, Louisville.

Eaton, J.H., 2004, Meditating on the Psalms, Westminster John Knox Press, Louisville.

Eaton, J.H., 2003a, The Psalms: a historical and spiritual commentary - with an introduction and new translation, T\&T Clark International, London.

Eaton, J.H., 2003b, Review: 'Strophic structure and theological commentary', Journa of Theological Studies 54(2), 627-629. http://dx.doi.org/10.1093/jts/54.2.627

Eaton, J.H., 2000, 'Review: “City of our God"', Journal of Theological Studies 51(2), 602-604.

Eaton, J.H., 1997, Mysterious messengers, A course on Hebrew prophecy from Amos onwards, SCM, London.

Eaton, J.H., 1995a, 'Psalms of the way and the kingdom: a conference with the commentators', JSOT, suppl. ser. 199.

Eaton, J.H., 1995b, 'Festal drama', in R.P. Gordon (ed.), The place is too small for us. The Israelite prophets in recent scholarship, pp. 247-251, Eisenbrauns, Winona Lake.

Eaton, J.H., 1994, Interpreted by love. Expositions of 40 great Old Testament passages, Bible Reading Fellowship, Oxford.

Eaton, J.H., 1989, The contemplative face of Old Testament wisdom, in the context of world religions, SCM Press, London.

Eaton, J.H., 1986, Kingship and the Psalms, 2nd edn., JSOT Press, Sheffield.

Eaton, J.H., 1985, Job (Old Testament guides), JSOT Press, Sheffield.

Eaton, J.H., 1984, The Psalms come alive: an introduction to the Psalms through the arts, Mowbray, London.

Eaton, J.H., 1981, Vision in worship: the relation of prophecy and liturgy in the Old Testament, SPCK, London.

Eaton, J.H., 1980, First studies in Biblical Hebrew, University of Birmingham, Birmingham.

Eaton, J.H. (ed.), 1979a, Horizons in Semitic Studies, University of Birmingham, Birmingham.

Eaton, J.H., 1979b, Festal drama in Deutero-Isaiah, SPCK, London.

Eaton, J.H. (ed.), 1978, Readings in Biblical Hebrew II, University of Birmingham, Birmingham.

Eaton, J.H. (ed.), 1976a, Readings in Biblical Hebrew I, University of Birmingham, Birmingham.

Eaton, J.H., 1976b, Kingship and the Psalms (Studies in Biblical Theology 2/32), SPCK, London.

Eaton, J.H., 1976c, 'A New Gattung in O.T. Literature? A Hebrew Teacher's Dream', Journal for the Study of the Old Testament 1, 67-70. http://dx.doi. org/10.1177/030908927600100205
Eaton, J.H., 1967, Psalms: introduction and commentary, SCM Press, London.

Eaton, J.H., 1961, Obadiah, Nahum, Habakkuk, and Zephaniah: introduction and commentary, SCM Press, London.

Firth, D.G., 2005, Hear, o Lord. A spirituality of the Psalms, Cliff College Publishing, Calver.

Gunkel, H., 1933, Einleitung in die Psalmen: die Gattungen der religiosen Lyrik Israels, Vandenhoeck \& Ruprecht, Gottingen.

Johnson, A.R., 1944, Sacral kingship in ancient Israel, Wales University Press, Cardiff.

Johnson, A.R., 1967, Sacral kingship in ancient Israel, 2nd edn., Wales University Press, Cardiff.

Le Roux, J., 1997, 'Our historical heritage', Old Testament Essays 10(3), 401-423.

Lombaard, C., 2011a, 'Biblical Spirituality and Interdisciplinarity: The Discipline at Cross-Methodological Intersection', Religion \& Theology 18, 211-225. http:// dx.doi.org/10.1163/157430111X613737

Lombaard, C., 2011b, "Genesis 22 as a "test case" for the emergent discipline of Biblical Spirituality', paper read at the International Organisation for the Study of the Old Testament congress, University of Helsinki, Finland, 01-06 August 2010. Ekklesiastikos Pharos.

Lombaard, C., 2008a, 'Spirituality: sense and gist. On meaning, God and being', in P.G.R. de Villiers, C.E.T. Kourie \& C. Lombaard (eds.), The spirit that empowers: Perspectives on spirituality, Acta Theologica, suppl. ser. 11

Lombaard, C., 2008b, 'What is Biblical Spirituality? Perspectives from a minor genre of Old Testament scholarship', in H. Blommestijn, C. Caspers, R. Hofman, F. Mertens, P. Nissen, \& H. Welzen (eds.), Seeing the seeker. Explorations in the discipline of Spirituality, Studies in Spirituality, suppl. ser. 19, pp. 139-153.

Lombaard, C., 2006a, 'Four recent books on spirituality and the Psalms: some contextualising, analytical and evaluative remarks', Verbum et Ecclesia 27(3), 909-929.

Lombaard, C., 2006b, 'Teks en mens. JH le Roux se lees van die Bybel binne die konteks van hoofstroom-eksegese in Suid-Afrika', Old Testament Essays 19(3), 912-925.

Lombaard, C., 2003, 'The Old Testament in Christian spirituality: perspectives on the undervaluation of the Old Testament in Christian spirituality', HTS Theological Studies 59(2), 433-450.

Lombaard, C., 2000, 'By implication. Didactical strategy in Psalm 1', Old Testament Essays 12(3), 506-514.

Lombaard, C., 1999, 'Sermon: Even the worst of times (Psalm 137), Maseru Anglican Cathedral, Lesotho', The T.E.E. Journal 3, 139-141.

Mahoney, E.J. (ed.), 2005, Scripture as the soul of theology, Liturgical Press, Collegeville.

Mowinckel, S., 1922, Psalmenstudien II: Das Thronbesteigungsfest Jahwas und der Ursprung der Eschatologie, Skrifter utgitt av Det Norske Videnskaps-Akademi i Oslo, Kristiania.

Pacini, D.S., 1991, 'Reading Holy Writ: the locus of modern spirituality', in L. Dupré \& D.E. Saliers (eds.), Christian spirituality III. Post-reformation and modern, pp. 174-210, Crossroads, New York.

Runia, K., 1988, 'Towards a biblical theology of experience', in I.H. Marshall (ed.), Christian experience in theology and life, pp. 175-198, Rutherford House Books, Edinburgh.

Schneiders, B., 2002, 'Biblical Spirituality', Interpretation 56(2), 133-143. http:// dx.doi.org/10.1177/002096430005600202

Stuhlmueller, C., 2002, The spirituality of the Psalms, Liturgical Press, Collegeville, Minnesota.

Thiselton, A.C., 2009, Hermeneutics. An introduction, William B. Eerdmans, Grand Rapids.

Thurston, B., 2000, 'The Study of the New Testament and the Study of Christian Spirituality (WCC Report 1994. Report of the Consultation on Christian Spirituality for our times)', Mid-Stream 33(4), 471-481.

Von Herder, J.G., 1782/1783, Vom Geist der ebräischen Poesie. Eine Anleitung für die Liebhaber derselben und der ältesten Geschichte des menschlichen Geistes, s.n., Dessau.

Waaijman, K., 2004, Mystiek in de psalmen, Uitgeverij Ten Have, Baarn.

Waaijman, K., 2002, Spirituality: forms, foundations, methods, Peeters, Leuven.

Wilks, J.G.F., 2003, 'The prophet as incompetent dramatist', Vetus Testamentum 53(4), 530-543. http://dx.doi.org/10.1163/156853303770558202 